\title{
9. THE PRESENCE OF THE PHENOMENON OF ARTISTIC SYNESTHESIA IN PAINTING
}

Eleonora Florea,
Stela Cojocaru $^{239}$

\begin{abstract}
The present study elucidates the presence of the phenomenon of artistic synesthesia in painting, describes the types of synesthesia and their effects, sensory symbiotic relationships, correlations with different genres of art: dance, music, literature. Early art forms were initially distinguished by an archaic and primary syncretism, being interconnected and dependent on each other. Subsequently, during the historical evolution, these artistic forms were dispersed in separate art genres, while preserving this specific intermediarity and interrelation, of artistic synesthesia. Synesthetic phenomena in painting are stylistically interconnected with music, dance, literature.
\end{abstract}

Key words: synesthesia, sensory symbiosis, synesthetic perception, psychedelic painting, musical painting

\section{Introduction}

The earliest forms of artistic activity, dating from the Paleolithic, attest to an exclusive affiliation for ritual and magical cults (fertility, calendar agrarian, hunting, etc.), initially distinguished by an archaic syncretism on the levels of different cultural manifestations - plastic, sound, kinetic, verbal, dramatic, etc. The subsequent evolution of artistic creativity led to its gradual segregation into separate species and the emergence of distinct art genres with their own ontological characteristics (plastic, dramatic, musical arts). This separation and morphological differentiation of artistic species is not absolute even at the present time, this phenomenon being preserved throughout history as a communion based on specific intermediation and interrelationship, of artistic synesthesia.

Synesthesia (fr. Synesthésie, gr. Synaisthesis - "to perceive together") is a phenomenon that involves the interference of two or more fields of art; from the point of view of psychoneurology, it defines a specific way of intercalated sensory perception of different senses: visual, olfactory, auditory, gustatory, kinetic, tactile. Random connections and the association of several types of perception occur automatically, unconsciously, in different ways, often spontaneously, and lead to the appearance of certain unusual sensations. Synesthetic perception is sometimes also considered a "superior perception", attributing a metaphysical allure. The sensory impulses in the case of this phenomenon are transmitted to a certain sense, but are subsequently received by another sense. As a result, some "mixed" sensations appear: the visualization of an image, for example, can cause sound sensations, and the perception of different sounds - amazing color combinations. Synesthetic perception can involve different senses: tastes, smells,

239 Professor PhD., Academy of Music, Theatre, Fine Arts from Chişinău, Republic of Moldavia, email: eleonora.florea@mail.ru

240 Candidate Doctoral, Free International University from Chişinău, Republic of Moldavia, email: aspasia_86@yahoo.com 
textures, architectural forms, spatial location, etc.

The neurological phenomenon of synesthesia, in which, at the perceptual level, a single stimulus can trigger a series of sensory responses in the case of the receptor, refers to particular situations in which there is a process of unification of two or more types of sensations or sensory perceptions. Thus, synesthesia designates the spontaneous association between two or more sensations of a different nature; doubled by the establishment of significant correspondences, which lead to the appearance of the particular impression that the respective sensations are correlated or symbolically associated by the metaphorical transposition of the data of one sense into the language of another sense [2, p.1].

Synesthesia, as a phenomenon, is most common among artists, following these unusual sensory processes, they interpret the surrounding reality in an absolutely different way from the rest of the world, and their senses produce unique associations. The two types of synesthesia: perceptual synesthesia (based on various associations of several perceptual channels - sight, hearing, taste, etc.), and conceptual synesthesia (ability to see abstract concepts - units of time), places marking this phenomenon in the artistic, subjective, intuitive and often not fully valued area.

\section{Discussions}

Artists create their works according to their own synesthetic perceptions, which in most cases are of a particular nature. Particular synesthesia is often a innate phenomenon, the number of such people is not very large - the innate synesthetic capacity is not common in artists or ordinary people. Therefore, some of them looked for different methods to induce synaesthetic states, which can reverse or interconnect the senses - the case of psychedelic painting and the ways to access it (characterized by explosive effects of light, color, sound atmosphere, etc., evoking visions, hallucinations, dreams, similar to the consumption of specific products). Currently, painters who opt for this artistic genre, try to achieve the same creative effects and interconnected correlations of the senses, through healthy synesthetic experiences, focused on examples and studies of the correspondence of the senses and sensations, artists of previous periods.

Psychedelic art relates quite truthfully the effect of these interconnections of the senses, and psychedelic experiences are very similar to synesthetic ones. This artistic style played a big role in art, culture, being associated quite well with the "hippy" era and with innovative and unique sensual experiments. The special style of psychedelic art, inspired by experienced visions, is recognized by its kaleidoscopic patterns, fractal schemes and backgrounds, bright and intense colors, the presence of symmetry, three-dimensional shapes and textured images, which combined variously, can create unique and extraordinary art pieces. The popularity of psychedelic art, as well as synesthetic art, has not decreased over time, but on the contrary, has grown slowly, a process reflected in multiple studies and interest in unusual artistic sensations and experiences. Often, artists create works to induce states of synesthesia in viewers, those who perceive it, to distort sensory impulses and create a specific perception. From this point of view, artistic 
synesthesia is perceived as a metaphor, frequently approached in various genres of art: painting, music or literature (sound color, rhythm, tact, etc.).

The mysterious connection and interaction of the senses and sensations has interested great thinkers and scientists from ancient times to contemporary research: Aristotle (he spoke in his treat "On the Soul" about a "common sense"), Goethe, Leibniz, Francis Galton (Charles Darwin's cousin; in 1880 he described and named the phenomenon), the physicist Christian Bergson, Louis Bertrand Castel (he built a color musical organ), Richard Cytovici, a contemporary American psychoneurologist. Physicist Isaac Newton, following research, assumes that musical tones and color tones are wavelengths that have common frequencies; tries to link the sound oscillations with the respective light waves. According to the scientist, the distribution of white light in the chromatic spectrum is analogous to the distribution of musical tones in the octave; identifying at the same time, the seven spectral colors equivalent to the seven musical notes.

Artists also devoted themselves to the study of this interesting phenomenon, given the fact that in many of them these processes were innate: the painters W. Kadinsky, M. Čiurlionis, V. Van Gogh, etc., the composers N. Rimsky-Korsakov, A. Scriabin, poets and writers Ch. Baudlaire, P. Verlaine, M. Tsvetaeva, B. Pasternac, V. Nabocov. The phenomenon of artistic synesthesia was also explored by many Romanian researchers: Mihaela Mancaș, Mircea Scarlat, Tatiana Curmei, Oana Boc, Mircea Borcilă, Roxana Maria Burducea (the latter defended her doctoral thesis at the University of Art and Design, Cluj - Napoca , 2014). Artistic synesthesia, therefore, can be born (genetically inherited quality) or acquired, created (following artistic experiences) - this conception was demonstrated and formulated by Dr. Hugo Heyrman. There are several types of synesthesia, each with its distinct contribution to artistic experiences:

1) chromesthesia - is a specific type of synesthesia, in which colors are automatically associated with sounds or words, the most commonly used and plenary type in painting. The form given by synesthesia associates and perceives each other's colors and sounds: sound, music, can cause the visualization of colored images, and colors in turn - can "sound" and arrange themselves into pictorial musical compositions. For this type of works or compositions is specific the presence of musical rhythm on canvas, specific and recognizable, due to the rhythmic organization of lines, shapes, colors, features and graphic character of existing lines, the type of compositional model used; their development and orientation in a certain direction in the plastic space.

2) grapheme-color synesthesia - type where a sign, a certain shape, a letter of the alphabet, is associated with a certain color. Most often, artists associate certain shapes with certain colors, a process that led to the emergence of unique stylistic and associative interferences - abstractionist painting. Having a well-structured semiotic aspect, the shape-color plastic sign - called chromomorph (colored shapes), where the shape amplifies, completes or diminishes with the meanings of colors $[4$, p.36].

Shape-color (chromorpheme) induces a concomitant visual perception of the shape and color of the object or colored surface, and the final visual image results 
from their simultaneous overlap. The researcher Dan Mihăilescu, in his book "The language of colors and shapes", formulates the concept, according to which all the elements integrate in one and form - the chromorpheme, which means line, and surface, and volume, and color. He considers that shapes and colors cannot be separated, they are relatively "solidary" to each other, constituting at the same time common elements of all objects of the material world.

\section{Results}

In painting, form, along with color, is one of the main semantic tools with a well-pronounced aesthetic and emotional side [4, p.26]. The pictorial form is inseparable from color, they always evolve together, constituting themselves as an integral and organic whole. The expressive force of forms is always sustained by color. The artist W. Kandinsky developed a whole theory of correspondences of shapes and colors. He believed that this inevitable relationship between shape and color determines the effects of shape on color. The painter wrote that each color is organically linked to a form by their energetic properties, both representing an entity with its own personality and individuality [10, p.51].

W. Kandinsky, (endowed with innate synesthetic abilities), argued that any form has its own sound, and the reciprocity of effects and correspondences between form and color, is that the value of some colors is accentuated by shapes: colors sound more intense if associated with sharp shapes, and deep colors are better enhanced by round shapes. The artist thus created specific associations and correspondences between form and color:

square - associated with red, the color of matter, heavy, opaque, corresponds well with the statics and weight of the square furnace;

triangle - symbol of thought, weightless, aggressive, fighting; well associated with yellow;

circle - a symbol of concentration itself, is well associated with the clear blue color;

trapezoid - associated with the color orange, dynamic, cheerful;

cone - associated with green (blue circular base + yellow triangular shape);

oval - associated with violet [ibid, p.57]. According to this system, Bauhaus students were trained (1919 - 1933).

The symbol is also related to shape (symbolic shape) and color - the solar circle is rendered in most cases yellow or red; rhombus, square - is connected with black earth or brown field; aquatic symbols - with white and blue colors, etc.

3) spatio-temporal synesthesia - is associated with a location in space (numbers, directions, cardinal points, months of the year, days of the week, etc.). Spatial synesthesia has a virtual character and is based more on the presence and effects of optical illusions (op-art), the illusion of three-dimensional space, the creation of different spatial planes and depth in the painting. This type of artistic synesthetic vision brought spatial three-dimensionality in painting, the creation and plastic rendering of the third dimension through various illusions, the introduction of geometric perspective in paintings, developed the trompe l'oeil technique, support and pictorial technique well placed during the Renaissance. The illusory 
renaissance representation of the three-dimensionality of space directed the transition to panoramic art and that of images with intentional synesthetic potential, such as the series of landscapes with water lilies signed by C. Monet [1, p.365].

4) personification - type of synesthesia that associates the sequences of numbers, days of the week, letters, with particularities or forms, well-defined mental images, of spatial order. Numbers, letters, shapes, have their own personality, receive a gender, or accept other personal qualities. It is known for sure that the ancient philosopher and mathematician Pythagoras (500 BC) had this type of synesthesia, related to numbers and personality: any number had, in his opinion, its own personality: male or female, beautiful or ugly, perfect or not ( number 10 was considered perfect).

Art has involved various stylistic interferences since ancient times - of literature (the presence of biblical, mythical, historical heroes, on canvas), music (musical instruments, scores, in the Dutch static natures, of musicians), dance (which appears on ancient frescoes, to Pieter Bruegel, Impressionists), with painting, an act carried out constantly and intrinsically throughout history. Myth, ballad, storytelling, narration, appear in painting since prehistoric times (cave paintings, hunting scenes and secular life, etc.), thus replacing the written and verbal by their communicative function...

Dance, as a form of artistic expression, approaches painting through the presence of the common character of the same ideas, emotions, and feelings, through the same nonverbal and gestural communication, equally dependent on cultural, artistic, aesthetic and moral summonses. Visual artists always found in dance a prolific source of inspiration, insisting on rendering on their canvases the beauty of the body, the aesthetics of the gesture, the virtuosity and the artistic sublime. Namely dance was one of the first subjects represented by the visual arts: cave drawings attest to this by the presence of human figures in various poses of dance, which were part of sacred rituals or ceremonies ("Apollo's Dance with the Muses" - Florence, Pitti Palace; scenes of vachanalia with dances in honor of Bahus, represented on the walls of ancient Roman or Greek villas; statuettes and figurines of dancers, etc.). The costumes specific to a certain dance (Viennese waltz, Argentine tango, Balkan dance, Russian Cossack, Brazilian samba, etc.) emphasize the importance and presence of the relationship between painting and this kind of art.

Dance has been a favorite subject of many painters, devoting to the subject a whole series of paintings: the impressionist Edgar Degas with his frail and diaphanous ballerinas ("Ballet Rehearsal", "Dance Class", etc.); Henri Matisse ("The Dance"); Toullouse-Lautrec ("Jane Avril"); Peter Breugel ("Peasant Dance"); Pablo Picasso ("The Three Dancers", where the famous artist depicts romantic and sensual dance, with morbid allusions). Edvard Munch also approached the theme of dance in his works ("Dance of Life"), where different characters dance with women dressed in red, white (represents hope) and black (disappointment). "Union Chorus" is one of the favorite subjects of Romanian and Moldovan artists, where catching the characters in a common circular dance 
suggests and signifies integrity and strength, the importance of this moment (Alexei Luca "Union Dance", street art, Timisoara). The connection between dance and painting, not being clearly visible, is felt by all artists to a different extent and style of approach.

Synesthesia brought in painting specific means and the diversification of artistic manifestation processes, creating unique correspondences between colors, shapes, sounds, symbols, analogies and metaphors for different human emotions and feelings. This phenomenon makes possible any perceptual-associative combination. The creative methods and means of painters, based on synesthetic effects, are focused on transforming a sense into the language of another sense, using for this purpose various symbolic, metaphorical associations, by graphic or chromatic rendering of an idea, concept, sensation, phenomenon, feeling, shape or object. Directing artists' attention to this phenomenon, instilling synesthetic accents in works of art, accentuated during the emergence of the symbolist current, led to the emergence of so-called "musical paintings" (M. K. Čiurlionis, W. Kandinsky). More and more symbolist artists bring back on canvas the themes of literary works: poetry, ballads, myths, etc. (G. Moreau, G. Klimt, M. Vrubel, N. Roerich).

Painting combines in a harmonious synesthetic symbiosis with music through common terms and concepts for both arts (sound, rhythm, tone, range), the presence of analogies and parallels, the succession of shapes, lines, color surfaces, touches, and the succession of sounds of musical compositions. The relationship between color and musical tone is based on the associations between color and sound: seven spectral colors correspond to the seven musical notes; on the association of light, intense and bright colors - with high sounds; and dark colors with low musical tones. This relationship results from the properties of sound, musical harmonies to evoke colors or to arrange colors in melodic compositions, hence the expressions: "to paint music", "chromatic symphonies", "music frozen in stone" - in the case of Antonio Gaudi's work).

Musical instruments also have certain correspondences and associations: piano - sadness; violin - melancholy; whistle, flute - restlessness; harp - cosmic vibrations. Lighter musical tones trigger a more intense perception of color, which becomes more vivid and bright [13]. The music was also mastered by the supreme gods: Apollo (seven-stringed harp), Orpheus (lyre), Pan (panpipe), Krishna (whistle), the muses of the arts and other characters, who transmitted the vibrations of "music from the divine spheres" to ordinary people.

One of the first theorists, who tried to explain the correlation between color and music, the symbiosis of color and sound, was Wassiliy Kandinsky. Of particular interest for abstract pictorial compositions and color-sound musical analogies, the artist formulated them in the theory of correspondence and equivalence of chromatic tones with musical ones, of form with sound; brings in pictorial context sound and music; establishes rules of reciprocity between color, sound and shape; associates colors with songs of different musical instruments (blue - with the flute, azure - with the cello, red - with the sound of the trumpet); conclusions established and expressed in the volume "The spiritual in art". The 
artist calls the paintings with musical terms: "compositions", "improvisations", "impressions", considering music the essential source of inspiration of his abstract paintings [10, p.53-55]. He also spoke about the "dance of the future", which will "embody" as a third element - the scenic composition of monumental art; the scenic composition will initially consist of three elements: 1) the musical movement, 2) the pictorial movement, 3) the artistic choreographic movement $[10$, p. 103].

Inspired by Wagner's music, Scriabin, Kandinsky elaborates the series of works Composition I (1907) - Composition X (1939), a monumental work with the status and qualities of chromatic symphony, and his "Improvisations" through its dramatic aspects, resemble piano concert pieces. In these "musical paintings", characterized by a purified plastic space, the lack of any epic elements; the artist opts for complicated rhythmic compositions with strong signals of the symphonic principle [10, p. 116]. The choral compositions of Mozart, Beethoven, the artist associated them with the great, solemn and calm architecture of the Gothic style, considering their works belonging to the forms of transition [10, p. 117]. Musical sounds such as - fugue, alegro, prelude, andante, expressed them in painting through geometric elements (circles, semicircles, angles, straight lines and curves) [10, p. 24].

Another artist marked by synesthetic experiences was Vincent Van Gogh, who declared that sounds have color, and listening to music had striking effects for him: each heard note evoked a certain color. The arousal through musical stimuli of chromatic sensations was a peculiarity for the artist, which gave his paintings an exceptional expressiveness. The energetic touches of paint, arranged abundantly on the canvases, give every detail movement and vibration, endowing each painting with its own life. The colors, especially - yellow and blue, had a special place in his creation: "Starry Night", "Sunflower"; yellow was considered the color of friendship, and blue associated with the night sky. The presence of sensory feedback and chromesthesia (associations of sounds with colors) in his works, allowed the artist to feel the painting, in a particular way and unique to him, to see reality in a more strange and privileged way, fascinating in the current time.

The creation of the painter Micolaus Ciurlionis, is marked mainly by the philosophical theme, focused on the emotional-sentimental side of the inner human. His landscape compositions, based on visual-sound equivalents, with images of hills, houses, trees, placed at different heights and inscribed as a portable; repetition of motifs, rhythms, sizes ("Sonata of the Pyramids"), phantasmagoric images (astronomical signs, metaphors, complex symbols), and structural complexity of the universe ("Rex", "The Story of the Citadel"), the decorative plastic language of his works with stylized shapes, are transposed in conventional spaces (cosmic, unreal from the past or future), with contrasting color or in silver tonal harmony, which evokes a dream world [7, p.2].

The culture of antiquity, based on the syncretism of the arts, is also characterized by the confluence of image and word, which are often identified as a whole: the word was considered an image, and the image described a word (pictograms, symbolic and ornamental signs, narrative cave paintings). The word 
begins to distinguish itself from the image following the evolution of abstract human thought; but this connection does not disappear forever, their relationship remains close for a long time. Artists try to bring to the canvases the qualities of the word - expression, richness, poetics (painting - "poetry in colors"). Ancient and Renaissance painting possessed descriptive qualities and properties - narrative, telling through painted or drawn images - biblical stories, epics, legends, immortalized in church and secular frescoes, historical scenes, etc.

Painting and literature are close in that both are languages with specific functions and common messages. The use of literary procedures (metaphor, allegory, symbolization, personification, etc.) in painting allowed a broader rendering of complicated and contradictory abstract ideas, and the representative artistic form, resulting from these correlations, more complexly renders the content of the artistic message, feelings and the artist's vision. The tendency towards high ideals and superior feelings, complex ethical problems and philosophical searches, existential meanings, the painters materialize them on canvas in eternal subjects: life, love, kindness, beauty, suffering, death. The compositional and artistic-plastic searches, the acquisition of metaphors, allegories, symbols, personifications, took the painting out of the narrow and formal space of the visual lexicon.

Painting and literature, through these synesthetic correlations, gave birth to various ambiguous genres: lyrical, romantic, poetic, allegorical, metaphorical, philosophical, symbolist painting. Lyrical painting ("lyre" - the attribute of Apollo, god of light, music, poetry, sun) depicts the ideas, thoughts, feelings of the painter, through the prism of lyrical symbolism and melancholic vision of the world, spiritual-artistic experience, fully manifested in lyrical landscapes (F. Goya, E. Delacroix, W. Turner, Heerdale). Metaphor is a common semantic concept in artistic creations, which is manifested through the figurative and expressive language of symbols, artistic associations, coding messages, breaking from reality, and creating new worlds, imaginary and fantastic, realities and spatio-temporal dimensions [ 9, p.1].

Symbolism brings in the plastic space the symbolic significance, the synesthetic accents, stylizations of the compositional elements, symbols from mythology, folklore, dreams, imaginary, unconsciously accessed; paints spiritualized nature, the phenomena of the world in a suggestive symbolicmetaphorical manner, focused on melancholic "tone", images and objects with an esoteric connotation (G. Moreau "Presus and Andromeda" - the symbol of the serpent, G. Klimt "The Kiss" - forms symbolic with erotic context: the square - of masculinity, the circle - of femininity, E. Munch "Scream” - contorted human figure - symbol of fear, despair, O. Redon „Ghost”, „Spider” - ghostly forms from parallel worlds) [ 8, p.26].

Allegorical painting expresses imperceptible abstract concepts and ideas (good, evil, power, love, death) through concrete images of living beings, animals, figures and forms to which certain symbolic meanings have been historically attached (Femida - personification of the law, Death - skeleton with scythe, Motherhood - Madonna with babies, Love - beautiful goddesses). Narrative 
compositions give the impression of unfolding an imaginary story, using as forms of expression - fables, parables, metaphors, comparisons and personifications (living beings, abstracts, objects, phenomena, states of nature, feelings). The image of the lion, for example, is traditionally associated with power, the eagle with vigilance, the owl - with wisdom (it sees in the dark, where others do not see). Allegories were very widespread in the painting of the Middle Ages, Renaissance, Classicism, Romanticism [12, p.138], ("Spring" S. Botticelli, "Sacred Allegory" F. Bellini, "Allegory of Painting" I. Vermeer).

\section{Conclusions}

Painting, music, dance, literature, passed through the prism of human subjectivity and spiritual vibrations, were related by the way of reflecting reality, retransforming into visible artistic images, loaded with metaphorical and symbolic meanings. The chromatic and spatial possibilities of music, the plasticity of dance, the inertia of the word, allowed the embodiment of the most creative ideas in the visual arts and painting.

\section{References}

1. ARNHEIM, R. (2011) Arta și percepția vizuală. Ed. Polirom, București

2. BURDUCEA, R. M. (2014) Sinestezia în arta contemporană, rezumat teză de doctor, UAD Cluj - Napoca. Disponibil: http://www.uad.ro/ (download - 11.10.2020)

3. ELIADE, M. (1994) Imagini și simboluri. Ed. Humanitas, București

4. MIHĂILESCU, M. (1980) Limbajul culorilor şi al formelor. Ed. Ştiinţifică şi Enciclopedică, București

5. PĂSTRĂGUȘ, M. Simbol și semnificație in filosofie și artă. Disponibil: http://www.slideshare.net/ (download - 19.09.2020)

6. SILLAMY, N. (1996) Dicționar de psihologie. Ed. Univers enciclopedic, București

7. URSACHI, R. (2017) Coordonate muzicale în creația lui M. Čiurleonis. În: Probleme ale ştiinţelor socioumanistice şi modernizării învăţământului. [online]. (Materialele Conferinţei "Probleme ale ştiinţelor socioumanistice şi modernizării învăţământului", Universitatea Pedagogică de Stat „Ion Creangă“, Chișinău, 24 martie 2017). Seria 19, Vol. 3, pp. 234-239. Disponibil: https://ibn.idsi.md/ro/vizualizare_articol/72777. (download - 19.09.2020)

8. URSACHI, R. (2011) Modalităţi de expresie plastică a spaţiului compoziţional în pictura simbolistă. În : Revistă de știinţe socioumane. Universitatea Pedagogică de Stat „Ion Creangă“, Chişinău. 2011, Nr. 3 (19), pp. 25-28. ISSN 1857-0119/ISSN 2587330X.

9. VERŞINA, M. Metafora şi structura ei semantică. În: Analele Ştiinţifice ale Universităţii de Stat "Bogdan Petriceicu Hasdeu" din Cahul. 2007, Nr. 3, pp. 63-65. ISSN 1875-2170. Disponibil:

https://ibn.idsi.md/ro/vizualizare_articol/33683 (download - 15.11.2020)

10. KANDINSKY, W. (1994) Spiritualul în artă. Ed. Meridiane, București

11. ВЫГОТСКИЙ, Л. (1987) Психология искуства, Изд. Педагогика, Москва

12. ГРОМОВ, Е. (1984) Начала эстетических знаний, Изд. Советский художник, Москва 